\title{
Olga Nowicka
}

Uniwersytet Jagielloński, Kraków

\section{Kariki Jogijara i wedyjska tradycja wznoszenia ołtarzy ofiarnych w Kerali}

Klasę tekstów zwanych śulwasutrami (skr. śulvasūtra) historia literatury lokuje zazwyczaj w kulminacyjnej (bądź schyłkowej, jak wolą inni) fazie epoki wedyjskiej. Uważa się na ogół, że dzieła te uzupełniają od strony technicznej nader bogatą, powstającą od ok. $1500 \mathrm{r}$. p.n.e. literaturę związaną z liturgią wedyjskiego ceremoniału ofiarnego (Gonda 1975: 22). Z czasem rozwój literatury związanej w ten lub inny sposób z praktyką lub ideologią wedyjskiego rytuału ofiarnego doprowadził do uformowania się korpusu tekstów rytualistycznych, reprezentujących specyficzny system wiedzy określanej przez niektórych współczesnych badaczy mianem science of ritual. Uważa się, że stanowi on prawdopodobnie bezprecedensowe zjawisko w dziejach starożytnych cywilizacji (Staal 1996: 350). Niezbędna dla przeprowadzania wielkich ceremonii liturgicznych wiedza techniczna usystematyzowana została przy pomocy nowej formy literackiej - sutry. Przykładem tego gatunku była klasa traktatów normatywnych poświęconych geometrii sakralnej, zwanych śulwasutrami. Impulsem do skodyfikowania zawartej w nich wiedzy specjalistycznej stała się prawdopodobnie z jednej strony konieczność zagwarantowania precyzji konstrukcji ołtarza, a z drugiej kontekst historyczno-społeczny w postaci rywalizacji ugrupowań bramińskich o prawo do reprezen- 
towania kanonicznej postaci tradycji wedyjskiej, przechowanej w kolektywnej pamięci danej grupy lub tzw. szkoły wedyjskiej.

Wznoszenie ołtarzy ogniowych w rozmaitych kształtach, towarzyszące najbardziej spektakularnym wedyjskim rytuałom klasy śrauta, wiązało ze sobą pewne wymagania konstrukcyjne. Właściwe wymierzenie terenu, na którym miała powstać arena rytualna (skr. yajñaśā$l \bar{a})$ oraz nakreślenie skomplikowanych form ołtarzy ofiarnych, które łączyło się z przekształceniami figur oraz powielaniem ich pola, niosło za sobą konieczność opanowania określonej wiedzy geometryczno-matematycznej. Efektem jej skodyfikowania były właśnie śulwasutry (Bhagwat 2009: 162-165). Chronologicznie wcześniejsza literatura brahmaniczna, której celem była interpretacja rytuału (skr. arthavāda), mimo iż podawała wymiary poszczególnych elementów składowych areny rytualnej, z oczywistych względów nie dostarczała opisu sposobu ich tworzenia. Tej potrzebie sprostała klasa tekstów zwanych śulwasutrami. Były one uzupełnieniem dla literatury śrautasutr, systematyzując ową wiedzę specjalistyczną i tworząc w ten sposób korpus podręczników technicznych dla adhwarju (skr. adhvaryu) (tamże: 162-163).

Termin śulwa (skr. śulva), zawarty w nazwie tych traktatów, oznacza sznur bądź linę (Monier-Williams 2005: 1084, 2), których używano podczas dokonywania pomiarów placu ofiarnego. Jest on derywatem od sanskryckiego rdzenia śulv, tłumaczonego jako 'wymierzać', 'tworzyć', 'formować' (Sarasvati Amma 1999: 16). Słowo to jednak nie występuje w sutrach, w których zastępowane jest wyrazem radźdźu (skr. rajju) o tym samym znaczeniu (Thibaut 1875: 2).

Louis Renou wymienia osiem śulwasutr: Baudhajana (Baudhāyana), Apastamba (Āpastamba), Manawa (Mānava), Wadhula (Vādhūla), Waraha (Varāha), Katjajana (Kātyāyana), Hiranjakeśi (Hiraṇyakeśi) oraz Laugakszi-Śulwasutrę (Laugākși-Śulvasūtra) (Renou 1957: 43, 51). Datta dodaje jeszcze jedną: Maitrajana-Śulwasutrę (Maitrāyaṇa-śulvasūtra) (Datta 1932: 2). Ich powstanie Max Müller datował na okres od ok. 600-200 r. p.n.e., George Thibaut zaś uznał, że IV i III w. p.n.e. są najpóźniejszym możliwym czasem ich kompozycji. Finalnie A. Seidenberg datuje te dzieła na ok. 500-300 r. p.n.e. (Seidenberg 2010: 104). Przyjmuje się, że większość śulwasutr powstała przed współcześnie bardziej znanymi sutrami gramatycznymi Paniniego (Pāṇini), na co wskazywać miałby ich język (Sarasvati Amma 1999: 15).

Najstarszymi, a zarazem najważniejszymi, przez wzgląd na treść w nich zawartą, były Baudhajana i Apastamba-Śulwasutra. Co ciekawe, w Baudhajana-Sulwasutrze, powstałej najwcześniej - prawdopodobnie jeszcze przed V w. p.n.e. (Pingree 1981: 4) - znajduje się re- 
guła równoznaczna z twierdzeniem Pitagorasa. Przy jego pomocy tekst ten opisuje, jak skonstruować kwadrat równy sumie dwóch danych kwadratów oraz kwadrat równy różnicy dwóch danych kwadratów (Seidenberg 2010: 98). Tekst czasami posługuje się również tym twierdzeniem, obrazując tworzenie kąta prostego, choć nie jest to regułą (tamże: 95). Przy użyciu prawie tych samych słów, definicję zasady równoznacznej z twierdzeniem Pitagorasa podają także śulwasutry Apastamby oraz Katjajany (tamże: 98).

Sutry przeważnie rozpoczynały się od podania ogólnych zasad wykonywania pomiarów (skr. māna, vimāna), w tym również wymieniały podstawowe założenia geometryczne ${ }^{1}$. Następnie przechodzono w tekście do wskazania właściwego doboru miejsca instalacji trzech ogni ofiarnych (skr. agni), ustalenia właściwych relacji przestrzennych między nimi oraz odpowiedniego wymierzenia, a w końcu i skonstruowania ołtarzy, na których miały być ulokowane. W dalszych partiach tekstu szczegółowo nauczano, jak wznosić spektakularne ołtarze ofiarne, w różnych kształtach w zależności od efektu, jaki poprzez odprawienie rytuału chciał osiągnąć ofiarnik (skr. yajamāna). Przeznaczone były one do rytuałów somy (skr. soma - roślina, z której wytwarzano trunek wprowadzający w stan ekstatyczny). Opisy te poprzedzały definicje jednostek miar oraz lista używanych w konstrukcji cegieł (skr. isțakā), wraz z objaśnieniem sposobu ich wyrobu (Thibaut 1875: 3).

Charakterystyczny lakoniczny styl, właściwy gatunkowi sutry, w swym zamierzeniu prawdopodobnie był narzędziem mnemotechnicznym, służącym ułatwieniu i ustabilizowaniu ustnego przekazu. Jednak z upływem czasu zastosowana oszczędność słów, metajęzyk (skr. paribhāsāa), charakter prezentowanych zaleceń oraz występująca współzależność między tekstami sprawiały, że treść sutr stawała się coraz mniej zrozumiała. Zrodziło to konieczność powstania literatury uzupełniającej, której celem było objaśnienie enigmatycznych zasad zawartych $\mathrm{w}$ sutrach. W odniesieniu do wedyjskiego rytuału śrauta (wielkie, publiczne ceremonie ofiarne, podczas których używano trzech ogni rytualnych) zadanie to spełniały m.in. praktyczne podręczniki dla rytualistów - prayoga; komentarze - vyākhyā; zwięzłe dzieła objaśniające - vrtti oraz kārikā, przedstawiające reguły dotyczące rytuału w skondensowanej, wierszowanej formie (Gonda 1977: 653-661). Zamysłem towarzyszącym ich twórcom było zapewne wyjaśnienie niejasnych nakazów, zredukowanie przepisów uznanych za

\footnotetext{
${ }^{1}$ Co ciekawe, różne śulwasutry, podając wspomniane reguły, często posługiwały się tymi samymi bądź prawie tymi samymi słowami (Thibaut 1875: 44).
} 
zbędne, uzupełnienie brakujących reguł, wskazanie alternatywnych rozwiązań, jak również, być może, kontrola nad kanoniczną wykładnią tekstu. W konsekwencji nasuwa się pytanie o stopień autorytatywności wspomnianych komentarzy. Skonfrontowanie klasycznego tekstu normatywnego z późniejszym o wiele stuleci autorytatywnym komentarzem może dać wgląd w procesy kontynuacji i innowacji w odniesieniu do przekazu wedyjskiego kanonu literatury rytualistycznej oraz pozwolić na wyznaczenie trajektorii ewolucji praktyki rytuału wedyjskiego.

W pierwszym tysiącleciu naszej ery wedyjski rytuał śrauta zaczął powoli, lecz sukcesywnie, zanikać w miejscu swych narodzin, czyli na północy Indii. Jednak ok. I w. p.n.e. oraz w V w. n.e. historia notuje dwie fale migracyjne na południe Indii: najpierw braminów zwanych pūrvaśikhā, a następnie braminów zwanych aparaśikhā (Mahadevan 2003: 3). W okresie Sangam ${ }^{2}$ bramini purwaśikha w pełni osiedlili się już na południu Indii. Spośród nich prawdopodobnie wywodzą się zamieszkujący Keralę bramini nambudiri, którzy do dziś kontynuować mają - jak sami twierdzą oraz jak twierdzi część badaczy - starożytną tradycję odprawiana wedyjskich rytuałów klasy śrauta (tamże: 3). Jednak sposób, w jaki obecnie praktykowane są przez nich wedyjskie rytuały klasy śrauta, różni się pod niektórymi względami od zaleceń klasycznych traktatów normatywnych. Pod wpływem zmieniającego się kontekstu historycznego i obszaru geograficznego rytualizm wedyjski zaczął ewoluować. Proces ten można zaobserwować wnikliwie, studiując i zderzając ze sobą rytualistyczną literaturę sutrową z późniejszymi komentarzami. Te ostatnie mogą dostarczyć wiedzy o modyfikacjach, którym poddana została praktyka rytuału śrauta oraz o jego procesie adaptacji na innym gruncie niż ten, z którego wyrósł. Autorytet komentatora, przenikanie się wpływów różnych szkół rytualizmu, a w końcu i aspekty praktyczne, miały wpływ na ostateczny kształt żywej tkanki, którą jest rytuał. Powstałe różnice można zatem zaobserwować, konfrontując starożytne teksty normatywne z unikalną żywą tradycją rytualizmu wedyjskiego w Kerali, opierającej się na późniejszych komentarzach.

Przykładem komentarza do wedyjskiego traktatu normatywnego, który pozwala przyjrzeć się wspomnianym kwestiom kontynuacji i innowacji w kanonie literatury rytualistycznej są skomponowane najprawdopodobniej około XVI w. w sanskrycie Kariki Jogijara (mal. Yogiyāruțe Kārikāa) (Namboodiri 2002: 142). Jest to komentarz do

${ }^{2}$ Okres w historii Indii Południowych, swoją nazwę wywodzący od sławnych ugrupowań poetów i uczonych powiązanych z miastem Maduraj (ok. III w. p.n.e.-IV w. n.e). 
powstałej prawie dwa tysiące lat wcześniej, najprawdopodobniej ok. VI-V w. p.n.e. Baudhajana-Śulwasutry. Autorstwo tego tekstu przypisuje się keralskiemu ascecie (skr. yati) z rodu braminów nambudiri. Miał on wywodzić się prawdopodobnie z Taikkāț Mana (Edappal), czyli jednego z dwóch rodów waidikanów (skr. vaidika - posiadający przywilej praktykowania rytualizmu wedyjskiego), należących do osady (grāma) Covvaram. Zanim został sannjasinem (skr. saṃnyāsin), Jogijar (Yogiyār) prawdopodobnie nosił imię Nilakanthan Nambudiri. Tekst jego autorstwa składa się z dziewięćdziesięciu czterech strof (skr. śloka) i zawiera opis sposobów konstruowania ołtarzy właściwych keralskiej tradycji ofiarnej. W tekście zapisana podobno jest data jego skomponowania przy użyciu systemu Katapayādi $i^{3,4}$, natomiast na samym końcu utworu znajduje się fragment o następującej treści:

pūrvācāryaih pañcapatravișayāḥ kārikās tu yāḥ |

krtās tad vrttirupena ślokāś caite mayā krtāḥ || 94 ||

Owe strofy przeze mnie skomponowane $w$ formie writti [sa komentarzem] do karik [skomponowanych] przez dawnych nauczycieli, które dotyczyły jedynie [ottarza typu] pańćapatra ${ }^{5}$.

Papierowy manuskrypt Karik Jogijara jest przechowywany (a przynajmniej był jeszcze do niedawna) przez Taikkata Nilakanthana Nambudiriego w Edappal w środkowej Kerali. Sanskrycki tekst w owym manuskrypcie zapisany jest w piśmie malajalam. Powstało również tłumaczenie tego utworu na język malajalam, którego skomponowanie jest datowane na ok. 1750 r. Dwa papierowe manuskrypty tłumaczenia przechowywane są obecnie w Taikkāṭ Mana w Edappal, natomiast manuskrypt spisany na liściach palmowych znajdować ma się rzekomo w Pandal Mana, niedaleko Trichuru. Tłumaczenie nosi tytuł Agniyute Kanakkukal (Pomiary Agniego) (Sivanandan 2010: 63). Jego autorem najprawdopodobniej był członek tego samego rodu, co sannjasin Jogijar - autor karik w sanskrycie.

Jak już wcześniej wspomniano, tekst zawiera opis trzech typów ołtarzy ogniowych konstruowanych podczas wedyjskiej ceremonii agnićajany (skr. agnicayana; agni 'ołtarz', cayana 'budowanie', 'wzno-

\footnotetext{
${ }^{3}$ System ten polega na przypisywaniu literom pisma konkretnych cyfr w celu ułatwienia zapamiętywania liczb w postaci słów bądź całych wersów.

${ }^{4}$ Owa formuła zapisana w systemie Katapajadi brzmi āsit karmtoyam.

${ }^{5}$ Jeżeli nie zostało zaznaczone inaczej, tłumaczenia $\mathrm{z}$ sanskrytu zawarte w tekście są mojego autorstwa.
} 
szenie'). Jest to spektakularny rytuał ofiarny, podczas którego główny ołtarz ogniowy, identyfikowany z ciałem ofiarnika, powinno się wznosić w kształcie ${ }^{6}$ ptaka z rozłożonymi do lotu skrzydłami (Staal 2010b: 125-138). Ptak ów w tekstach rytualistycznych określany jest sanskryckim terminem śjena (skr. śyena), a nazwa ta przez badaczy była tłumaczona różnorako, m.in. jako „jastrząb”, „sokół” lub „orzeł”. Pewne jest jedynie, że termin ten określa zwinnego i szybkiego drapieżnika.

Agnićajana należy do skomplikowanych ceremonii somicznych i według tekstów normatywnych powinna trwać wiele dni i nocy (w tradycji keralskiej jest to dwanaście dni rytualnych ${ }^{7}$ ). Jednym $\mathrm{z}$ jej bloków składowych, ustawionym jako kulminacyjna sekwencja, powinno być ofiarowanie somy (Staal 1996: 71-77). Rytuał ten należy do klasy wedyjskich rytów śrauta. W Indiach był już znany na początku I tys. p.n.e. ${ }^{8}$

Trzy typy ołtarza w keralskiej tradycji ofiarnej, które zostały opisane w sanskryckich Karikach Jogijara, to: pițhan, pañcapatrika oraz șatpatrika ${ }^{9}$. Wszystkie one budowane były $\mathrm{w}$ kształcie drapieżnego ptaka określanego sanskryckim terminem śjena, a każdy z nich miał zwyczajowo odpowiadać jednemu z etapów rozwoju ptaka. Pierwszy z nich, pițhan, według keralskich waidikanów - praktyków rytualizmu wedyjskiego - miał wyobrażać pisklę (typ ten zatem nazywany był z sanskrytu bāla). Ołtarz ten był najbardziej schematyczny i przez to najprostszy w konstrukcji. Według zaleceń znajdujących się w tekście miał być zbudowany $\mathrm{z}$ czterech czworoboków (Namboodiri 2002: 108, 116).

\footnotetext{
${ }^{6}$ Taittirija Samhicie wymienione są również inne możliwe kształty ołtarza wznoszonego podczas rytuału agnićajany. Były to m.in.: ołtarz w kształcie czapli (skr. kañkacit), ołtarz w kształcie koła rydwanu (skr. rathacakracit), ołtarz w kształcie wiadra (skr. droṇacit) oraz ołtarz w kształcie żółwia (skr. kūrmacit). Rodzaj ołtarza budowanego podczas rytuału miał zależeć od efektu, jaki poprzez odprawienie ceremonii chciał uzyskać ofiarnik (Taittirìya Saṃhitā, 5.4.11).

${ }^{7}$ Podczas wielodniowego procesu rytuału ofiarnik jest zamknięty wraz z żoną $\mathrm{w}$ przestrzeni ceremonii.

${ }^{8}$ Świadczy o tym fakt, że już w Taittirija Samhicie agnićajanie poświęcone są aż dwie kandy (skr. kāndạ).

${ }^{9}$ Wymienione terminy pochodzą z języka malajalam.
} 


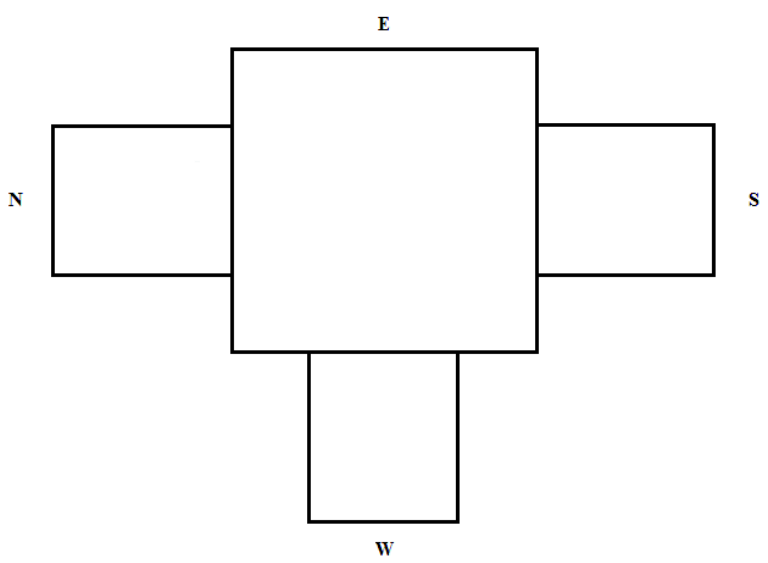

Ryc. 1. Model ołtarza ofiarnego typu pițhan ${ }^{10}$

Drugi typ ołtarza, pañcapatrika, był już zdecydowanie bardziej skomplikowany. Miał on przedstawiać młodego ptaka, stąd określany był przez waidikanów sanskryckim terminem yuvan. Składały się nań również cegły o bardziej skomplikowanych kształtach. W tym wariancie ołtarza skrzydła ptaka miały być zakrzywione, a ogon rozpostarty. Cechą charakterystyczną zaś dla tego typu miały być wyróżniające go skrzydła skonstruowane tak, by ich tylna krawędź była zwieńczona pięcioma trójkątnymi cegłami. Miały one imitować duże, sztywne pióra, nazywane lotkami pierwszorzędowymi, które u ptaków tworzą powierzchnię nośną skrzydła (tamże: 118).

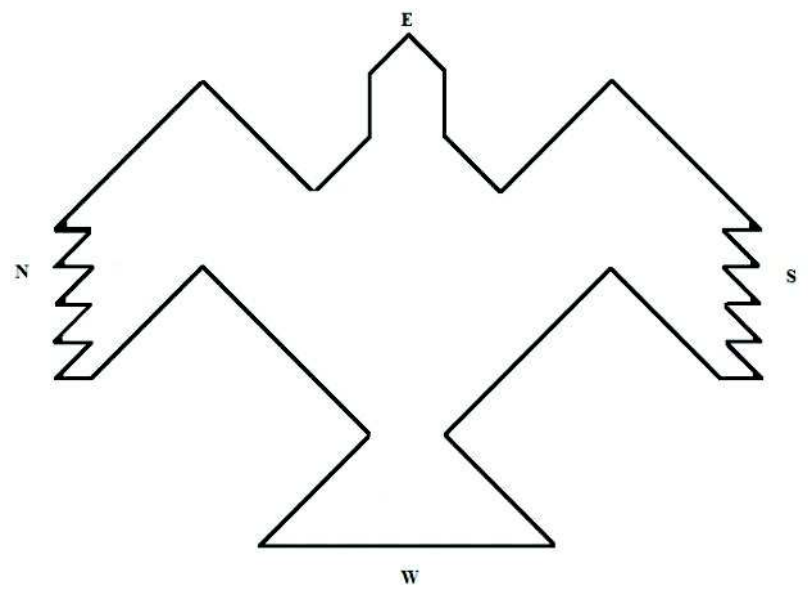

Ryc. 2. Model ołtarza ofiarnego typu pañcapatrika

${ }^{10}$ Zamieszczone w artykule ilustracje są mojego autorstwa. 
Ostatni, trzeci typ ołtarza w kształcie ptaka śjena - șațpatrika przez rytualistów określany w sanskrycie był jako vṛddha, czyli dorosły już ptak. Należał on również do bardziej skomplikowanych w formie konstrukcji. Od poprzedniego ołtarza pañcapatrika różnił się głównie dodatkowym, szóstym piórem wieńczącym tylną krawędź skrzydła (tamże: 108-110).

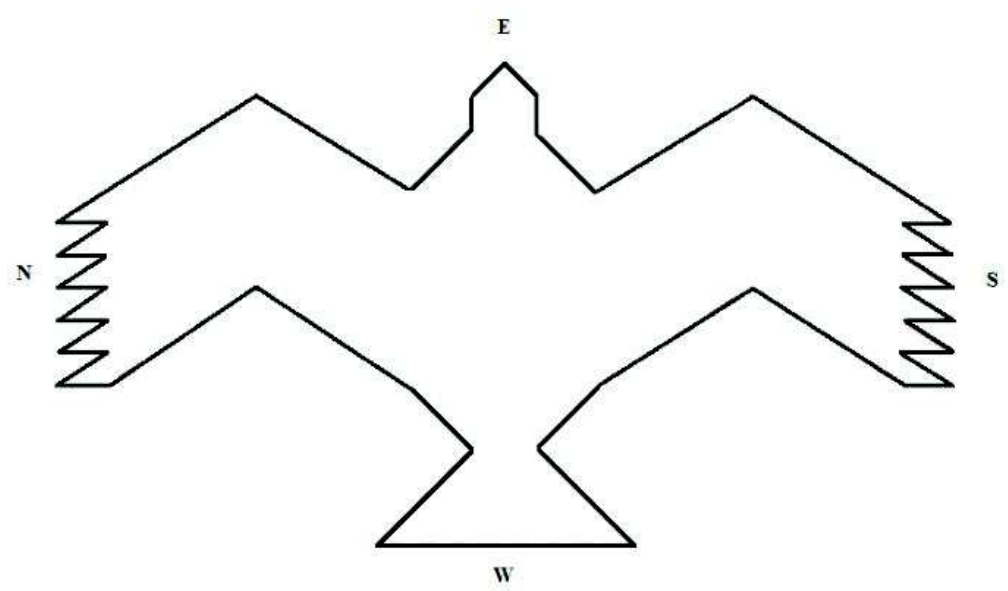

Ryc. 3. Model ołtarza ofiarnego typu șațpatrika

Ponadto w tekście Karik Jogijara pojawiają się nowe jednostki miary, nieznane twórcom wedyjskich śulwasutr. Są to mulakkol oraz viral. Jednostka mulakkol najprawdopodobniej wywodzi się od kija o tej samej nazwie, który służył w Indiach Południowych do dokonywania pomiarów podczas budowania domostw oraz podczas rzeźbienia w kamieniu. Prawdopodobnie nazwa ta wywodzi się z języka tamilskiego, w którym mulam oznacza „połowę długości ramienia”, natomiast kol - „kij”. Z kolei jednostka viral miała odpowiadać dwóm (skr.) angula . Jednostka miary mulakkol powinna zawierać dwadzieścia cztery virale (Sivanandan 2010: 62).

W Karikach Jogijara można znaleźć także nieznane twórcom wedyjskich śulwasutr przyrządy do dokonywania pomiarów. Były one charakterystyczne dla obszaru Kerali. Są to m.in. pasma zrobione z liści palm kokosowych, które miały być równe długości jednej aratni (w tłumaczeniu z sanskrytu 'łokieć' - wedyjska miara równa odległości od łokcia do czubka małego palca) (tamże: 62-63). 


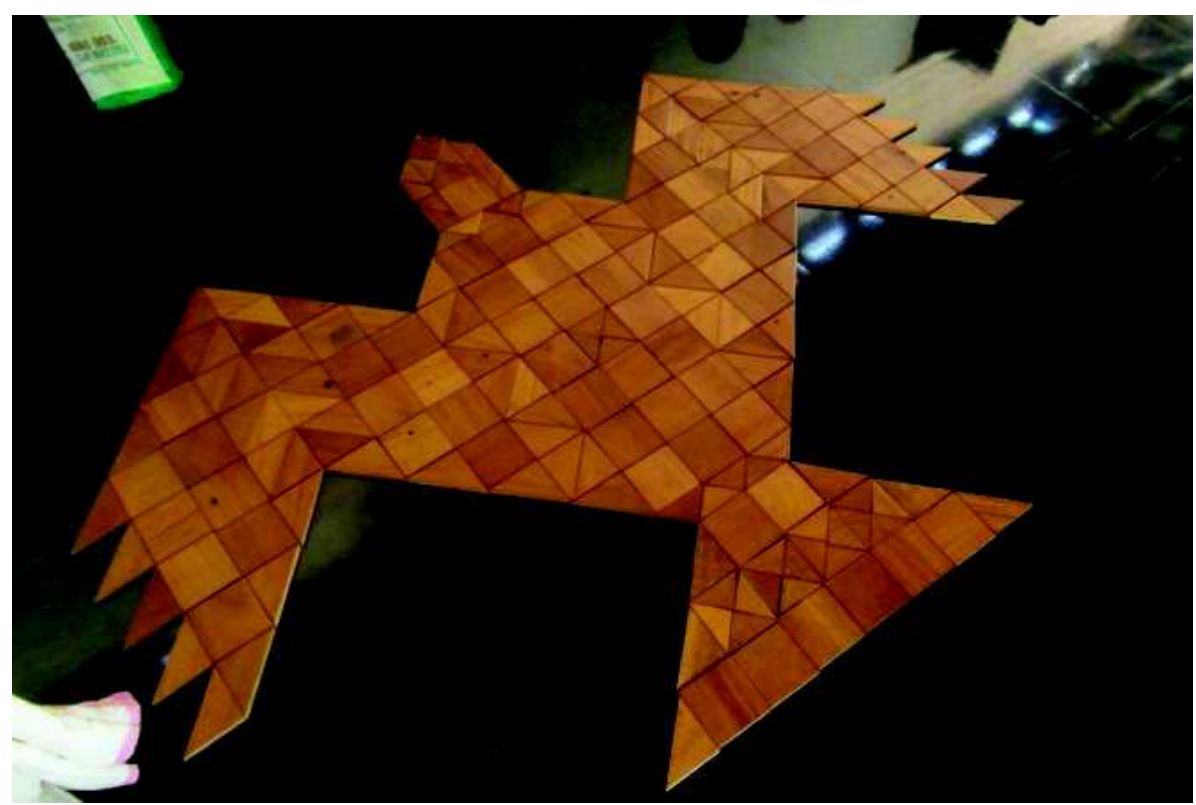

Ryc. 4. Model ołtarza ofiarnego typu pañcapatrika (Kavapra Mana, Edappal, Kerala, fot. Olga Nowicka)

Na podstawie tych obeserwacji i analiz porównawczych między tekstami oryginalnymi a powstającymi w ciągu wieków komentarzami do nich rysuje się pewna wyraźna trajektoria ewolucji w myśleniu o tym, co utrwalone w wedyjskich kanonach.

Co jednak najważniejsze, tekst Kariki Jogijara jest jak dotąd jedynym znanym sanskryckim komentarzem powstałym w okresie późniejszym niź śulwasutry epoki wedyjskiej, który porusza takie zagadnienia, jak właśnie konstrukcje ołtarzy ogniowych wznoszonych podczas odprawiania wielkich publicznych ceremonii ofiarnych typu śrauta. Wskazuje on na użycie nowych jednostek miary, a także nieznanych wcześniejszym tekstom narzędzi służących do pomiaru, charakterystycznych dla danej kultury lokalnej. Komentarz. ńw dostarcza opisu unikalnych form ołtarzy ofiarnych, takich jak pițhan, pañcapatrika oraz sațpatrika, które są produktem regionalnego wymiaru praktyki rytualizmu wedyjskiego. Stanowi również punkt wyjścia dla interpretacji rytuału agnićajany w tradycji wedyjskiej kręgu braminów nambudiri. Jest on zatem przede wszystkim unikalnym źródłem informacji o lokalnym wymiarze nieustająco ewoluującej praktyki wedyjskiej tradycji ofiarnej w Kerali i oferuje ciekawą perspektywę obserwacji zachodzących w niej procesów adaptacyjnych. 


\section{Bibliografia}

\section{Literatura podmiotu}

Yogiyāruțe Kārikā (kopia manuskryptu pozyskana z Taikkāṭ Mana)

\section{Literatura przedmiotu}

Bag, A.K. 2005. Vedic Mathematics. Seminar on Indian contribution to world civilization. Thane: Institute for Oriental Study.

Bhagwat, Bhagyashree. 2009. Kalpa-Vedānga: Origin and Development. Pune: Adarsha Sanskrit Shodha Samstha.

Datta, Bibhutibhusan. 1932. The Science of the Sulba. Calcutta: The University of Calcutta.

Gonda, Jan. 1959. Four Studies in the Language of the Veda. The Hague: Mouton Publishers.

Gonda, Jan. 1975. A History of Indian Literature. Vedic Literature: Saṃhitās and Brāhmanas. vol. I, fasc. I, Wiesbaden: Harrassowitz.

Gonda, Jan. 1977. A History of Indian Literature: Veda and Upanishads. The ritual Sūtras. vol. 1, fasc. 2. Wiesbaden: Harrassowitz.

Keller, Olivier. 2006. La figure et le monde. Une archeologie de la geometrie. Peuples paysans sans ecriture et premieres civilisations. Paris: Vuibert.

Mahadevan, T.P., Frits Staal. 2003. The Turning Point in a Living Tradition. Somayāgam 2003, Electronic Journal of Vedic Studies 10 (2003), 365-389.

Monier-Williams, Monier. 2005. A Sanskrit-English Dictionary. Delhi: Motilal Banarsidass.

Namboodiri, Govindan. 2002. Śrauta Sacrifices in Kerala. Calicut: University of Calicut.

Pingree, David. 1981. A history of Indian literature vol. 6. Scientific and technical literature. Jyotihśāstra: astral and mathematical literature. Wiesbaden: Harrassowitz.

Plofker, Kim. 2009. Mathematics in India. Princeton: Princeton University Press.

Renou, Louis. 1957. Vedic India. Calcutta: Routledge Courzon.

Sarasvati, Amma. 1999. Geometry in Ancient and Medieval India. Delhi: Motilal Banarsidass.

Seidenberg, Abraham. 2010. The Geometry of the Vedic Rituals. Frits Staal, Agni: The Vedic Ritual of the Fire Altar. vol. 2. New Delhi: Motilal Banarsidass, 95-126.

Sivanandan, D.S. 2010. New Found Hitherto Unknown Malayalam Text on Agni - New Insights on the Ślbasūtra Tradition in Kerala, Bulletin of Kerala Mathematics Association 6, 1 (2010), 59-67. 
Smith, Brian. 1989. Reflections on Resemblance, Ritual, and Religion. Delhi: Motilal Banarsidass

Staal, Frits. 1992. Māna: Bettina Bäumer, Kapila Vatsyayan (red.). Kalätattuaknćn A I.exirnn of Fundamental Concepts of the Indian Arts. vol. 2. New Delhi: Motilal Banarsidass, .

Staal, Frits. 1996. Ritual and Mantras: Rules Without Meaning. New Delhi: Motilal Banarsidass.

Staal, Frits. 2008. Discovering The Vedas: Origins, Mantras, Rituals, Insights. New Delhi: Penguin Books.

Staal, Frits. 2010. Agni: The Vedic Ritual of the Fire Altar. vol. 1. New Delhi: Motilal Banarsidass.

Thibaut, George. 1875. The Śulvasūtras. Calcutta: The University of Calcutta.

Witzel, Michael. 1997. The Development of the Vedic Canon and its Schools (Materials on Vedic Śākhās, 8): The Social and Political Milieu: Michael Witzel (red.). Inside the Texts, Beyond the Texts. New Approaches to the Study of the Vedas. Cambridge: Harvard University.

\begin{abstract}
Kārikās of Yogiyār and the Vedic Sacrificial Tradition in Kerala

The article concerns a hitherto little known Sanskrit text called Kārikās of Yogiyār - a medieval commentary to Baudhāyanasulvasūtra (ca. $5^{\text {th }}$ century $\mathrm{BC}$ ). The text in question deals with the construction of the Vedic altars specific to the Keralan sacrificial tradition. It is attributed to the ascetic Yogiyār from the village Taikkāt Mana (Edappal), who probably lived around $16^{\text {th }}$ or $17^{\text {th }}$ century. Kārikās of Yogiyār are presumably the only known independent sulvasūtra commentary in Sanskrit of the post-Vedic period.
\end{abstract}

Keywords: Vedic sacrificial tradition, śrauta ritual, agnicayana, Kerala, Nambudiri, Vedic altars, fire ritual 